\title{
The Relationship between Brand Image and Brand Trust in Sporting Goods Consumers
}

\author{
${ }^{1}$ Mohammad Deheshti, ${ }^{1}$ Javad Adabi Firouzjah ${ }^{*}$, ${ }^{1}$ Hossein Alimohammadi \\ ${ }^{1}$ Department of Sport Sciences, University of Qom, Qom, Iran.
}

\begin{abstract}
The image of a brand is the first word or image that is evoked in the mind of costumers immediately after hearing the brand name. The purpose of paying attention to the brand image is to ensure the proper mentality of consumers toward the brand. The components such as suitability, services, brand, variety, quality, and atmosphere form the brand image. The relationship between the brand image and other fields such as brand trust has been considered by researches and can play an effective role in improving the behavioral tendencies of costumers. This study is aimed to examine the relationship between foreign brand image and brand trust among buyers of foreign sports brands. The statistical population of this study consisted of 279 male and female athletes in city of Qom who were buying foreign sports brands. The data collection tool was brand image questionnaire and brand trust questionnaire with Cronbach's alpha of 0.87 and 0.88 , respectively. The results of Pearson's correlation test showed a significant relationship between image and brand trust ( $\mathrm{r}=0.68$ ). The components of brand image (brand, services, suitability, variety, quality, and atmosphere) with the coefficients of $0.39,0.53,0.45,0.55,0.51$, and 0.54 , respectively, had significant correlation with brand trust. The results of simultaneous regression analysis demonstrated that the components of services, variety, quality, and atmosphere could predict the significance of the brand trust among the buyers of foreign sports brands. Based on the results of this study, it seems that the focus on improving the components of services, variety in sale, attention to the quality of products and services, as well as developing a positive atmosphere for customers in providing sale services can have an effective impact on increasing brand trust and improving the behavioral tendencies of costumers.
\end{abstract}

KEY WORDS: Brand Image, Brand Trust, Sport Product, Customer.

\section{INTRODUCTION}

Today, sports have a great impact on the lives of people and develop specific values regarding fair play, sense of cooperation, tendency to perform physical activities, and respect for other athletes. It establishes mass relationship among people with common interests and is one of the growing business fields that provide many opportunities for development and prosperity
(1). The strong emotional connection between fans of athletic fields and their favorite teams or athletes is an important factor to establish the distinction between sports and other market fields, products, and services. The establishing mechanism of this kind of relationship is very important for sports organizations, because it connects sports fans to the values, interests,

*. Corresponding Author:

Javad Adabi Firouzjah

E-mail: jadabi@gmail.com 
roots, and traditions of their organizations and turns them into the brand ambassadors of those organizations. Nowadays, the importance and necessity of establishing supportive relationships between the company and customers are very important, and the appropriate relationship between the organization and its stakeholders leads to mutual trust and loyalty and strengthens the position of the organization in the market. In this regard, the best strategy is strategic marketing, which focuses on maintaining and increasing the participation and loyalty of fans and participants (2). Increased competition in sports industry and lack of inherent guarantee for the success of sports organizations have faced the manufacturers of sports goods and services with the reality that, regardless of their athletic success, they have persistent challenges in terms of achieving economic success. Thus, sports managers increasingly regard their organizations as the brands that should be managed, because their professional purpose is to create a strong brand, through which the behavior of external target groups can be influenced (1).

Brand is the identity tool of a company and its suggestions in the market. It is the mental image of customers toward the company, which is known as brand image. Brand and its image make the company's services real and help distinguish the company through its quality and resources in competitions. Brand is the supplementary part of an organization, which forms its promises about the performances and values of its products or services. Brand attracts costumers toward the organization and, at the same time, is a stimulus for establishing the associations of consumers. A strong brand is characterized with the familiarity and understanding of consumers, perceived quality, loyalty, and visibility in the market $(2,3)$. Establishing a strong brand in the market is one of the important targets of organizations, because it could provide many advantages for the company including less vulnerability to competitive environments, higher profit margin, more participation cooperation, as well as support and development of brand opportunities (4). Today, brand management has great importance in marketing management, particularly when organizations try to send their relationship messages in intangible and complicated ways. Many organizations believe that one of their most important features is the brand of their products and services. Many researchers such as Santos-Vijande et al. (2013) have mentioned that establishing strong brands is among the main factors in achieving competitive advantage as well as organizational durability and survival (5). For example, consumers use sportswear not only during their physical activity, but also at home, workplace, school, and other leisure centers. Also, the industries manufacturing sporting goods have the tendency for proper and athletic design of clothes, which are indispensable for each other (5).

Management of sports brands is a complicated issue which includes decisionmaking at different levels in the sports markets. Studies have demonstrated that, besides having a large number of consumers, the strong relationship of consumers and sports brands is very important. The relationship power is usually achieved via the participation and loyalty of consumers with brands. Filo, Funk, and O'Brien (2010) states that consumers with high loyalty and participation are more likely to follow the sports brands live through the media, buy more sports products, and evaluate the sponsors of sports brands more positively (6). Today, the brand image of a company is one of the most important assets of that organization that not only establishes a competitive advantage, but also helps the organization stay in the minds of its customers and results in the loyalty of customers to the organization. The concept of brand image has been discussed by different theorists and concepts such as brand identity, brand personality, brand awareness, brand importance, brand attitude, brand reputation, and company image are considered its synonyms. "The image of a company or organization includes all of the beliefs and perceptions about that organization" (2). In other words, brand image is the first word or image that is evoked immediately in the mind of costumers after hearing the brand name. Brand image is based on the concept of brand awareness, i.e. a person cannot have an image of the brand about which he/she is unaware. Many discussions have been made on the relationship of the constituents of brand image as well as 
brand image and its impact on the development of brand equity (7).

On the other hand, brand trust has not been greatly studied in the principles of branding and most of such considerations have been theoretical and conceptual; hence, few experimental works have been done in this field. The issue of trust has been considered in numerous fields such as management, psychology, sociology, economics, etc., but this concept was considered in 1990s as a common subject in the study of consumer behavior (8). This interdisciplinary interest has strengthened the concept of trust and, at the same time, challenged the integration of various aspects of trust and consensus on its nature. DelgadoBallester, and Munuera-Alemán (2005) defined trust as "ensuring that what is favorable for a person from the side of another person and what he/she is afraid of" (4).

In the field of relationship marketing, brand trust is regarded as an important factor in the success of marketing efforts (9). Trust is also defined as a relationship quality feature and considered an important determinant in the perception about the quality of services, loyalty, relationship between two parties, and cooperation. Trust is the key variable in the exchange network between the company and its numerous partners, because these variables (trust) encourage the company to spend on its long-term relationship. Accordingly, in another definition, brand trust is defined as follows: "the tendency of consumers in relying on the ability of brand to perform the expressed tasks and functions" (10). The concept of reliance in this definition of brand trust is essential. Sung and Kim (2010) suggested that there are two important factors and essential features in brand trust. The first factor is trustworthiness and the second one is expertise (10). Trustworthiness means the trust of consumers in the brand in terms of providing quality and honest functions. Expertise is the degree to which a brand is known by consumers to be skilled and knowledgeable. Expertise is the result of experience and training that the company has in manufacturing and providing services. One of the most important purposes of establishing brand trust is to achieve sustainable competitive advantage and, as a result, increased commercial performance of the company. Brand trust is obtained through a combination of familiarity, security, privacy, word of mouth, advertisement, and brand image. At the basic level, brand trust means the trust that the customer has in a specific brand. Brand trust means that brand value can be established and expanded through the management of some aspects which are beyond the expectations of customers about the product and its features. Brand trust is essential due to its impact on other brand components. Brand trust recognition includes expectations of reliability, sustainability, competence, and predictability of brand function. Becerra and Korgaonkar (2011) states that brand trust goes beyond the expectations of product features and functions and includes the emotional evaluation of products (11). Effective or emotional elements involved in the formation of brand trust include integrity, honesty, and benevolence. These components contain the expectations that are formed in the minds of customers and a brand responds to them through their products. Brand trust is effective for the purchase attitudes and behaviors, loyal behaviors, expectation about brand value, brand commitment, and brand reference. Even in the online environment, Becerra et al. states that brand trust increases the intention of online shopping for the brand.

Luhman (1979) states the social theory on trust which includes three systems: a) Familiarity, b) Reliability, and c) Trust (12). Familiarity is the introduction of trust and trust only occurs in the familiar world. Trust is required in the environments and times that have many perceived risks and, at other times, reliability or mere familiarity is enough to ensure and continue the movement. Brand establishment guarantees quality and security and brand trust is an important element in establishing a sustainable relationship between brand and consumers. In general terms, trust means the tendency to an organization (company) on the basis of the belief in the features and behaviors performed by the organization while facing the risk. A strong brand is a safe place for consumers, since it enables them to understand and perceive the brand suggestions and accept the lack of reliability and risks resulting from brand products. There is a mutual relationship between 
brand and consumers; consequently, trust is essential for both parties to expand this relationship properly and eliminate the perceived uncertainty existing in the purchasing behaviors of consumers.

Investigating the relationship between brand image and brand trust has been more considered recently by researchers in various fields. Awad Alhaddad (2015) used structural equation model to investigate the relationship between brand image, trust, and loyalty among 286 students from Institute of Business Administration. The results showed that brand image had a significant effect on brand trust and both factors of brand image and brand trust had significant effects on brand loyalty. He suggested that brand managers should have a general and universal model in order to increase brand loyalty (13). In the field of online games, the research results demonstrated that brand trust can be used as a partial mediator variable between brand image and online word of mouth $(13,14)$. Roets, Bevan-Dye, and Viljoen (2014) showed that in the field of social image and brand trust among the younger generation of mobile users in Africa, social image had a significantly positive impact on brand trust, growth of loyalty and, as a result, brand equity among consumers (15). Research has represented a significantly positive relationship between green brand image, green brand satisfaction and trust, green brand perceived quality, green brand loyalty, and green brand awareness. Therefore, it can be said that green brand image has a positive and indirect relationship with green brand perceived quality, green brand loyalty, and green brand awareness through satisfaction and trust (16).

Attention of different groups of people to sports for health and fitness, on the one hand, and development of different athletic fields in Iran, on the other hand, have led to the high growth in the market in terms of buying sports goods and people at different ages seek to buy a variety of sports goods. Famous foreign sports brands have also an extensive presence in the sports market in Iran and many people and athletes use the products, goods, and services of these sports brands. Sports brands such as Adidas, Nike, etc. have stores and present their products in Iran. These brands attempt to have a decent share in the market of sports goods and products in Iran. Nevertheless, few works have been already performed on examining the relationship of foreign sports brand images and its components with brand trust, and the manner of relationship is not clearly specified. Moreover, numerous research questions are asked about brand image and brand trust: "Is the image of sports goods consumers of foreign sports brands related to their trust in sports brand?", "Is there any relationship between the components of brand image and concept of brand trust?", and "Is it possible to predict trust in foreign sports brands considering the components of brand image?" This study is aimed to examine the relationship of brand image and its components with brand trust among the consumers of sports brands goods in city of Qom, Iran.

\section{MATERIALS AND METHODS}

Participants. The statistical population consisted of 279 subjects (155 men and 124 women) from athletes in city of Qom, who purchased foreign sports brands.

Instruments. The data collection tool was Vahie and Paswan (2006) brand image questionnaire (17), which involving 6 components of brand (6Qs), services (3Qs), suitability (3Qs), variety (3Qs), quality (2Qs), and 5 questions for atmosphere. In order to examine brand trust among the consumers of sports goods, Delgado-Ballester (2004) brand trust questionnaire with 7 questions was also used (3); Cronbach's alpha was obtained as 0.87 and 0.88 , respectively.

Data Analysis. In order to analyze the data at the descriptive level, mean and standard deviation were used. Normal distribution of the samples was confirmed using KolmogorovSmirnov test; hence, in order to examine the correlation among the research variables, Pearson's correlation parametric test was used and, to predict brand trust from the components of brand image, multiple regression method with simultaneous entry was utilized.

\section{RESULTS}

The subjects consisted of 155 men (56\%) and 124 women $(44 \%)$. The mean age of the men was 24.41 (standard deviation of 8.64) and that of women was 23.05 (standard deviation of 
6.99). Also, 62 subjects ( $22 \%$ ) had the education of under high school diploma, 94 (34\%) had high school diploma, 25 (9\%) had associate degrees, 76 (27\%) had Bachelor's degrees, and $22(8 \%)$ had Master's or higher degrees. In terms of marriage status, 192 subjects $(69 \%)$ were single, $85(31 \%)$ were married, and 2 did not state their marital status.

The mean score of brand image and brand trust among the consumers was examined using one-sample t-test. In this test, the assumed mean of population was considered 3 .

Table 1. Mean score of brand image and brand trust

\begin{tabular}{|c|c|c|c|c|}
\hline \multirow{2}{*}{ Variable } & \multicolumn{4}{|c|}{ Test value: 3} \\
\hline & Mean & $\mathbf{t}$ & df & p \\
\hline Brand image & 3.63 & 18.15 & 278 & 0.001 \\
\hline Brand trust & 3.62 & 14.50 & 278 & 0.001 \\
\hline
\end{tabular}

The results of single-sample t-test showed that the mean scores of brand image (3.63) and brand trust (3.62) were higher than the mean and in the favorable conditions.

The results of Pearson's test for examining the overall correlation between brand image and band trust showed a significantly positive relationship between brand image and brand trust $(\mathrm{r}=0.68)$. The results of Pearson's test for investigating the relationship between the components of brand image including brand, services, suitability, variety, quality, and atmosphere and brand trust represented that all the components of brand image had a significantly positive relationship with brand trust (Table 2).

Table 2. Correlation of brand image and its components with brand trust

\begin{tabular}{cc}
\hline Variable/Components & Trust \\
\hline Brand image & $\mathbf{0 . 6 8}^{\mathrm{a}}$ \\
- Brand & $0.39^{\mathrm{a}}$ \\
- Services & $0.53^{\mathrm{a}}$ \\
- Suitability & $0.45^{\mathrm{a}}$ \\
- Variety & $0.55^{\mathrm{a}}$ \\
- Quality & $0.51^{\mathrm{a}}$ \\
- Atmosphere & $0.54^{\mathrm{a}}$ \\
\hline \multicolumn{2}{c}{ a: Significant at $\mathrm{p}<0.05}$.
\end{tabular}
a: Significant at $\mathrm{p}<0.05$.

In order to predict the brand trust variable from the brand image components, multiple regression test with simultaneous entry method was used. The results of the regression analysis and F-test showed the possibility for predicting brand trust from the brand image components. There was a direct and significant correlation $(\mathrm{R}=0.69, \mathrm{p}<0.001)$ between the independent variables and dependent research variable. Also, the coefficient of determination, which represents the percentage of changes determined from the changes in the dependent variable of brand trust by the independent variable of brand image, showed that almost $49 \%$ of the total variance of brand trust changes was explained by the components of brand image (Table 3).

Table 3. Multivariate regression analysis for prediction between brand trust and brand image

\begin{tabular}{cccccccc}
\hline Model & Correlation & $\begin{array}{c}\text { Coefficient of } \\
\text { determination }\end{array}$ & $\begin{array}{c}\text { Modified } \\
\text { correlation } \\
\text { square }\end{array}$ & $\begin{array}{c}\text { Estimated } \\
\text { standard } \\
\text { error }\end{array}$ & F & p & $\begin{array}{c}\text { Durbin } \\
\text { Watson }\end{array}$ \\
\hline $\begin{array}{c}\text { Simultaneous } \\
\text { regression }\end{array}$ & 0.698 & 0.488 & 0.477 & 0.516 & 43.185 & 0.001 & 1.702 \\
\hline
\end{tabular}

The results of the multiple regression analysis in Table 4 show that the components of atmosphere, quality, variety, and brand services could predict brand trust among the consumers of foreign sports brand in city of Qom (Table 4).

Table 4. Regression coefficients for the prediction of brand trust based on brand image components

$\begin{array}{lllll}\text { Regression } & \text { Non-standardized coefficients } & \text { Standardized } & \text { t-value } & \text { Significance }\end{array}$




\begin{tabular}{cccccc}
\hline & \multicolumn{5}{c}{ coefficients } \\
\cline { 2 - 5 } & B & Std.Error & Beta & level \\
\hline Constant & 0.528 & 0.210 & & 2.518 & 0.012 \\
value & 0.093 & 0.053 & 0.089 & 1.767 & 0.078 \\
Brand & 0.122 & 0.060 & 0.123 & 2.038 & 0.043 \\
Services & 0.074 & 0.044 & 0.095 & 1.697 & 0.091 \\
Suitability & 0.180 & 0.047 & 0.217 & 3.783 & 0.000 \\
Quality & 0.131 & 0.052 & 0.143 & 2.507 & 0.013 \\
Variety & 0.241 & 0.046 & 0.275 & 5.203 & 0.000 \\
Atmosphere & & & & & \\
\hline
\end{tabular}

Therefore, the regression equation of brand trust, considering the predictor variables of brand image based on the data in Table 4, is as follows:

Trust $=0.52+0.24$ (atmosphere $)+0.18$ (quality) +0.13 (variety) +0.12 (services)

\section{DISCUSSION AND CONCLUSION}

The descriptive findings showed that the mean age of the buyers of foreign sports brands in city of Qom among both men and women was less than 25 years old. They were also single and $34 \%$ of them had high school diploma. This finding indicated the interest of young single boys and girls in foreign sports brands that can be considered by these brands in attracting customers and providing marketing programs. The results showed that the foreign sports brand image among the consumers of sports goods in city of Qom was favorable and, with the score of 3.63 , it obtained a significantly higher score than the mean. The mean score of brand trust among the consumers of foreign sports goods in city of Qom with the score of 3.62 was significantly higher than the mean and in good conditions. Although both components of brand image and brand trust were at favorable levels among consumers and buyers of sports brands, there was still a chance for improvement and development in both components in terms of achieving very favorable levels. This issue means that although foreign sports brands have a favorable image among costumers, these brands image can improve the brand image as well as costumers' brand trust to a higher level via using new programs and strategies and continuously increasing the quality of products and services, which could promote their competitive advantage in the market in a long run and guarantee their sustainability in the market which is full of competition for sports goods and products. Brand trust is the result of brand performance and brand ability in meeting the customers' expectations and establishing sense of satisfaction for the customers of sports goods. Due to the importance of brand trust in increasing customer loyalty to brand, the less the brand trust, the less satisfaction with buying the products and services; in contrast, the higher the brand trust, the more the satisfaction and loyalty to the brand would be. Establishing and maintaining customers' trust in brand are among the most important marketing programs of companies, especially when markets are very competitive and unpredictable and product distinction is decreased (8). In order to make people loyal to a brand and turn to the promoter and representative of a product or service, it is required to obtain their interest via their trust in the brand and organization. One of the most important cases in increasing the trust level of consumers in brand is the commitment of the company in terms of fulfilling the promises and slogans about the products and goods. The actions that cause the violation of the company's promises make consumers have weaker assessment and trust in the company. The weakness of the company in fulfilling the slogans and promises finally leads to less interest of people in the products of that company and switching to the products of other brands.

The results of the correlation tests in this research showed that, generally, brand image had a significantly positive relationship with brand trust and higher brand image among the costumers resulted in higher brand trust. Other researchers such as, Alhaddad (2015), Roets, Bevan-Dye, and Viljoen (2014) and Liao, Chung, and Widowati (2009) have reported similar results on the positive relationship of brand image and brand trust in their works (13-15). The results of the correlation test on 
the relationship between the subscales of brand image components showed that all the subscales including brand, services, suitability, variety, quality, and atmosphere had a significantly positive relationship with the brand trust variable. In this regard, it can be said that exercise and athletic activities, due to developing strong emotions and interest among people and via specific brands, gather people together and develop bonds among them. The image of an organization and company has an impact on its market performance, i.e. having good image and reputation is one of the major competitive advantages for sports organizations. Poor performance of organizations or sports teams leads to low self-esteem of fans, customers, and even staff and athletes. It can also have an impact on the brand image and reputation of the company or organization and reduce and weaken the brand image and reputation of the organization. Brand image and reputation of organizations are greatly influenced by the messages that organizations send to the environment. Brand image is also influenced by other external sources such as competitors, industry analysts, consumer activists, the media, etc. If organizations cannot properly fulfill their promises and obligations for products, goods, and services, costumers cannot rely on them and, as a result, their trust in companies is decreased. Brand trust is the tendency to rely on brand despite the brand risk or uncertainty. The behaviors of brands such as brand purchase, brand definition, and brand defense involve the risks that are decreased by brand trust. In this regard, Neal and Strauss (2008) (18) (18) stated that brand image as an organizational promise remains in the mind of consumers until the organization is able to meet this obligation (18).

The results of the regression test for predicting the brand trust variable based on the components of brand image variable showed that, among the components of brand image, the components of "service", "variety", "quality", and "atmosphere" were significant predictors for brand trust among the consumers of foreign sports brand goods. The results demonstrated that the mentioned factors had an impact on the trust of foreign sports brand consumers and the manufacturing companies of sports goods should consider these components in order to achieve and maintain the trust of costumers. The appropriate performance of sports brands in manufacturing and providing quality sports goods over time causes buyers and consumers of sports goods to have a good image about foreign sports brands. Paying attention to the components such as creating variety in sports products and goods makes buyers with different tastes meet their needs in the field of sports goods. Providing appropriate welfare services for customers during the purchase of brand products and post-purchase services such as guarantee of products as well as solving the problems of the consumers of the purchased goods and products increases and improves sports brands among consumers. On the other side, establishing a warm and friendly atmosphere in department stores presenting foreign brand goods and developing a peaceful environment for customers could improve the brand image among the customers of foreign sports brands. Creating a great experience for consumers is an important issue for commercial and professional sports organizations to establish their fan basis and increase the loyalty and purchase frequency of customers.

There are some limitations associated with the current research. First, there are few foreign brand sport products stores in Qom city and moreover, data were collected only from consumers of one city. Therefore, the sample may have relatively homogeneous characteristics and interests. The next phase of the study can be aimed at finding the relationship between sport consumers' personalities and a sport brand image and trust. Future study may develop a theoretical framework to investigate the relationship between the antecedents of brand image and trust with moderating variables and consequences (e.g., brand choice, brand purchase, brand loyalty).

\section{APPLICABLE REMARKS}

- Brand image is a suitable predictor of brand trust and can influence it. Through improving their brand image, companies can win their customers' trust to their products.

- Through paying more attention to the atmosphere of the shops, adding more variety to the products, and improving the quality of the products, the companies manage to win the trust of their customers. 


\section{REFERENCES}

1. Schade M, Piehler R, Burmann C. Sport club brand personality scale (SCBPS): A new brand personality scale for sport clubs. The Journal of Brand Management. 2014;21(7-8):650-63.

2. Rak A. Brand and corporate image of a sport organisation as a factor of building loyalty on example of rock climbing in Poland. International Journal of Innovation and Learning. 2015;17(2):205-16.

3. Delgado-Ballester E. Applicability of a brand trust scale across product categories: A multigroup invariance analysis. European Journal of Marketing. 2004;38(5/6):573-92.

4. Delgado-Ballester E, Munuera-Alemán JL. Does brand trust matter to brand equity? Journal of product \& brand management. 2005;14(3):187-96.

5. Santos-Vijande ML, del Río-Lanza AB, Suárez-Álvarez L, Díaz-Martín AM. The brand management system and service firm competitiveness. Journal of Business Research. 2013;66(2):148-57.

6. Filo K, Funk D, O'Brien D. The antecedents and outcomes of attachment and sponsor image within charity sport events. Journal of Sport Management. 2010;24(6):623-48.

7. Bibby DN, Woodside A, Megehee C. Brand image, equity, and sports sponsorship. Perspectives on CrossCultural, Ethnographic, Brand Image, Storytelling, Unconscious Needs, and Hospitality Guest Research. 2009;3:21.

8. Ha H-Y. Factors influencing consumer perceptions of brand trust online. Journal of Product \& Brand Management. 2004;13(5):329-42.

9. Carlson J, O'Cass A. Optimizing the online channel in professional sport to create trusting and loyal consumers: The role of the professional sports team brand and service quality. Journal of Sport Management. 2012;26(6):463-78.

10. Sung Y, Kim J. Effects of brand personality on brand trust and brand affect. Psychology \& Marketing. 2010;27(7):639-61.

11. Becerra EP, Korgaonkar PK. Effects of trust beliefs on consumers' online intentions. European Journal of Marketing. 2011;45(6):936-62.

12. Luhmann N. Trust and power 1st ed. Chichester, Toronto1979. $208 \mathrm{p}$.

13. Alhaddad A. A structural model of the relationships between brand image, brand trust and brand loyalty. International Journal of Management Research and Reviews. 2015;5(3):137-44.

14. Liao S, Chung Y, Widowati R, editors. The relationships among brand image, brand trust, and online word-ofmouth: an example of online gaming. IEEE International Conference on Industrial Engineering and Engineering Management (IEEM); 2009: IEEE.

15. Roets CRQ, Bevan-Dye AL, Viljoen WP. Influence of Social Image and Brand Trust on Mobile Phone Brand Equity amongst African Generation Y Students. Mediterranean Journal of Social Sciences. 2014;5(21):75-84.

16. Nazari E, Ghasemi B, Saeidi SS. Explain The Relationship Between Green Brand Image, Green Satisfaction and Green Trust and Factors Affecting on Green Brand Equity. Bulletin of the Georgian National Academy of Sciences. 2015;9(1):487-94.

17. Vahie A, Paswan A. Private label brand image: its relationship with store image and national brand. International Journal of Retail \& Distribution Management. 2006;34(1):67-84.

18. Neal WD, Strauss R. Value creation: the power of brand equity. 1st ed: South-Western Cengage Learning; 2008. $353 \mathrm{p}$. 